\title{
Foreign direct investment and technology spillovers in Mexico: 20 years of NAFTA
}

\author{
Enrique Armas ${ }^{1}$, José Carlos Rodríguez ${ }^{1 *}$
}

\begin{abstract}
This article analyses the development of technology capabilities in the manufacturing sector of Mexico during the last two decades. It has been argued that the inclusion of Mexico in the North America Free Trade Agreement (NAFTA) in 1994 would be enough to catch up with Canada and the United States. In this regard, trade liberalisation and foreign direct investment (FDI) would have been two strategic tools to close the technology gap between Mexico and its commercial partners in North America. Yet, after twenty years of NAFTA, it has been demonstrated that many indigenous firms in Mexico must develop an absorptive capacity to benefit from FDI. This paper suggests that the debate on the Asian miracle in the 1990s could be an adequate theoretical framework to discuss technology development and industrialisation in the case of emerging economies. In fact, this debate reveals two alternative approaches to explain the development of technology capabilities: (i) the accumulation view of growth, and (ii) the assimilation view of growth. Therefore, the Asian miracle exemplifies how entrepreneurship, learning and a supporting innovation policy could be an adequate strategy to benefit from FDI and technology spillovers in the case of emerging economies.
\end{abstract}

Keywords: Foreign direct investment; technology transfer; technology spillovers; trade liberalisation; North America free trade; agreement; Mexico.

Submitted: August $30^{\text {th }} 2017 /$ Approved: September $25^{\text {th }} 2017$

\section{Introduction}

Recent events in the world economy should be affecting the international business environment to a more protectionist trade system. In North America, for example, latest political changes in the United States mean the possibility of negatively affecting commercial flows and foreign direct investment (FDI) in the next years. These changes in the commercial policy of the United States are in opposition to the free trade principles of the North America Free Trade Agreement (NAFTA). Particularly, in the case of Mexico, NAFTA has meant the possibility of catching up with its North American partners to access modern technologies and to develop a more competitive economy. However, the results achieved in the North America region are controversial in that there is not convergence between Mexico and other NAFTA countries (Blecker, 2003, 2014; Hartman, 2010; Weisbrot et al., 2014). Indeed, it remains deep differences between Mexico and its North American partners in relation to per capita income, creation of new jobs, long-term increases in productivity, and so forth (Blecker, 2014; Weisbrot et al., 2014).

The rational of FDI in Mexico during the last twenty years has been the belief that it would generate externalities in the form of international technology transfer (Aitken and Harrison, 1999). In this regard, it has been suggested these externalities would be allocated in the form of technology capacity in domestic markets. Typically, technology transfer externalities would derive from firm-specific knowledge of foreign firms given that indigenous firms would be exposed to new products, production, marketing, and technical support (Aitken and Harrison, 1999; Behera, 2015; Erdal and Göçer, 2015). In addition, some scholars have pointed out the importance of foreign firms' nontangible assets as a means of increasing productivity among indigenous firms (Aitken and Harrison, 1999).
From a different perspective, the Economic Commission for Latin America and the Caribbean (ECLAC) has stressed the importance of FDI in Latin American countries during last decades (ECLAC, 2015). Accordingly, ECLAC mentions that FDI in Latin American countries has complemented the resources needed to ensure an adequate rate of economic growth. This report indicates that Brazil and Mexico have been the main countries receiving inward FDI in Latin America during the last decades (ECLAC, 2015). Specifically, in the case of Mexico, Paul Krugman said that even if inward FDI sharply increased in this country since the 1990s, the 'Mexican Miracle' has disappointed many people given that trade liberalisation has not been enough to achieve a better technological performance in Mexico (Saldaña, 2015). In the same way, Lederman and Maloney (2006) have pointed out that NAFTA has not been enough to close the technology gap between Mexico and its commercial partners in North America. Also, other scholars have suggested that in the case of many emerging economies, there are other important factors needed to successfully acquire and absorb new technologies from abroad (Dahlman, 1994; Hobday, 1995; Kim, 1998; Pack and Nelson, 1999).

However, from a theoretical perspective, two alternative approaches have emerged to explain the effects of FDI in emerging markets (Erdal and Göçer, 2015; Mahmood and Singh, 2003; Storm et al., 2005). The first approach concerns to how R\&D carried out in leading countries may affect the productivity of indigenous firms in emerging economies by means of trade, new investments, and technological/geographical proximity (Coe and Helpman, 1995). The second approach considers the association between the presence/intensity of trade liberalisation (imports) and FDI given that this process may increase the productivity of indigenous firms (Aitken and Harrison, 1999; Blomstrom and Kokko, 1998; Gorg and Greenway, 2004; Markusen, 2002). This approach also suggests that to take full advantage of FDI,

(1) Economic and Business Research Institute (ININEE), Universidad Michoacana de San Nicolás de Hidalgo, Mexico.

* Corresponding author: jcrodriguez@umich.mx 
indigenous firms must develop some complementary technological capabilities to successfully adopt new technologies and innovations from abroad (Dahlman et al., 1987; Lall, 1992). It is important to mention that the process of absorbing, adapting, or developing new technologies from further $\mathrm{R} \& \mathrm{D}$ in emerging economies is unique to each country, depending on their level of economic development and degree of modernisation (Gerschenkron, 1962; Prados de la Escosura, 2005).

From an empirical perspective, evidence demonstrates that there is not apparent convergence between technologies developed in newly industrialised countries and technologies developed in industrialised countries (Kim and Lau, 1994). In fact, lessons from newly industrialised countries demonstrate the fallacy of the traditional laissez-faire approach on markets (Krugman, 1994). Instead, evidence demonstrates that the growth of newly industrialised economies has been the result of sophisticated industrial and strategic trade policies that have promoted selective protectionism in some industries and firms (Krugman, 1994). In addition, some scholars have suggested the importance of developing an absorptive capacity to benefit from FDI and technology spillovers in the case of emerging economies (Glass and Saggi, 1998). In the case of emerging economies, firm capacity, geographic location and the ownership structure of foreign firms are the most important variables affecting the effectiveness of technology spillovers among indigenous firms in these markets (Behera, 2015; Liang, 2017). Actually it seems that indigenous firms with previous $\mathrm{R} \& \mathrm{D}$ investment and highly educated work force are more likely to effectively profit from technology spillovers spilled out by multinational enterprises (MNEs) (Blalock and Gertler, 2008).

Consequently, this paper aims to get insight on how inward FDI in Mexico have contributed to develop technology capabilities among indigenous firms after its inclusion in NAFTA in 1994. It is argued that Mexico's weak national learning and innovation capacity has been a critical missing complement to trade liberalisation to achieve a higher level of performance among indigenous firms (Lederman and Maloney, 2006). Therefore, the questions conducting this research are as follows: Is there any evidence of technology capacity developments from inward FDI in Mexico after its inclusion in NAFTA in 1994? And, what were the main variables promoting the development of a positive technology capacity effect from inward FDI on the Mexican economy after 1994 ?
In addition to this introduction, this paper is organised into four sections. Section 2 offers a literature review of the debate on FDI and economic growth and development from the perspectives of the accumulation view of growth and the assimilation view of growth. This section also discusses the main features characterising the process of technology transfer across NAFTA countries. Section 3 discusses an econometric model to test the possibility of finding technology capacity developments in Mexico after 1994. Section 4 analyses the main findings achieved in this research. Finally, Section 5 presents some conclusions.

\section{Literature Review}

\subsection{Foreign direct investment and economic growth}

In the decade of the 1990s, the debate on economic growth and development was mainly focused on East Asian countries (Dowling, 1994; Krugman, 1994; Kuznets, 1994). However, in the case of emerging economies, this debate opened up an important discussion on the relation between inward FDI, on the one hand, and economic growth and development, on the other. Typically, the discussion on East Asian countries confronted two alternative theoretical approaches (Mahmood and Singh, 2003): the accumulation view of growth, and the assimilation view of growth. The accumulation view of growth stressed the importance of investing in human and physical capital to increase economic growth (Collins and Bosworth, 1996; Young, 1995), while the assimilation view of growth stressed the importance of innovation, entrepreneurship and learning to improve economic growth (Dahlman, 1994; Hobday, 1995; Kim, 1998; Pack and Nelson, 1999). However, from the perspective of the accumulation view of growth, scholars suggested that high rates of savings and investments should be necessary to enable the use of technologies from abroad (Collins and Bosworth, 1996; Young, 1995). In contrast, from the assimilation view of growth, researchers argued that the critical source of economic growth would depend on high levels of productivity supported by learning, entrepreneurship and innovation when advanced foreign technologies were adopted in developing countries (Dahlman, 1994; Hobday, 1995; Kim, 1998; Pack and Nelson, 1999). Table 1 shows some literature in relation to these approaches. 
Table 1. Selected literature on FDI and the accumulation/assimilation view of growth

\begin{tabular}{cl}
\hline \multicolumn{1}{c}{ Author } & \multicolumn{1}{c}{ Variables } \\
\hline Collins and Bosworth (1996) & Physical and human capital \\
Dahlman (1994) & $\begin{array}{l}\text { Acquisition of foreign technology, domestic } \\
\text { technology effort, and human resource base }\end{array}$
\end{tabular}

Hobday (1995)

$\operatorname{Kim}(1998)$

Krugman (1994)

Pack and Nelson (1999)

Young (1995)
Flying geese model

Tangible capital and labour

Employment, education and physical capital stock, technological knowledge, and TFP

Several variables characterising both approaches of this debate
Contribution

Accumulation view of growth. High rates of economic growth by means of sustaining high rates of saving and investment.

Assimilation view of growth. Exposure to world competition might be improving productivity and quality and to keep up with new technologies.

Assimilation view of growth. The flying geese model underplays the significance of other economies as a market and as a source of technology and investment, and it must recognise the importance and significance of other factors in host countries (e.g. learning, entrepreneurship and innovation).

Assimilation view of growth. Economic growth as the result of the growth of tangible inputs, and not technical progress or the increase in TFP.

Accumulation view of growth. The maintenance of an open trading regime and targeted intervention regime for boosting promising successful sectors to catch up with industrialised countries.

Assimilation view of growth. Economic growth as the result of major changes in the structure of the economy including shifts in the size of the firms and the sectors of specialisation. Economic growth mainly results from entrepreneurship, innovation, and learning.

Accumulation view of growth. The maintenance of an open trading regime and targeted intervention regime for boosting promising successful sectors to catch up with industrialised countries.

Source: Authors' elaboration.

The accumulation view of growth thus suggested that economic expansion in emerging economies would be represented by the sum of two different forces (Krugman, 1994): (i) the growth in inputs (e.g. employment, education, physical capital, and so forth) and (ii) the growth in technology knowledge and management capabilities developments. However, this approach also stressed the importance of increasing the total factor productivity (TFP) to profit from technology advances and maintain a sustained rate of economic growth (Krugman, 1994). Accordingly, in the case of East Asian countries, factor accumulation, education improvements, high rates of investment and intersectoral transfers of labour were key factors to explain the high rates of economic growth during the 1990s (Young, 1995). Also, from this perspective, it has been argued that physical and human capital accumulation have been at the basis of the theoretical explanation on economic growth from the accumulation view in developing economies (Collins and Bosworth, 1996). Accordingly, in the case of emerging economies, the maintenance of an open trading regime to promote higher levels of economic efficiency and a targeting intervention regime to boost promising successful sectors have been two important policies to catch up with industrialised countries (Collins and Bosworth, 1996; Krugman, 1994; Young, 1995). Shortly speaking, some scholars have suggested that the high rates of economic growth observed in many East Asian countries during the 1990s were the result of exhibited range of government strategies that went from extreme laissez-faire to extensive intervention in specific sectors (Collins and Bosworth, 1996; Krugman, 1994; Young, 1995). From this perspective, these researchers have found that productivity gains, not capital formation, was the fundamental explanation on economic growth in East Asian countries during the 1990s, and therefore TFP has unexpectedly played a small role to explain economic growth in these countries (Collins and Bosworth, 1996; Krugman, 1994; Young, 1995).

On the other hand, the assimilation view of growth argued that economic growth in East Asian countries during the 1990s was accompanied by other major changes in the structure of these economies, namely firm size and sector specialisation (Pack and Nelson, 1999). These changes allowed a superior productive assimilation of capital flows through mastering new technologies adopted from advanced industrialised countries, mainly developing entrepreneurship, innovation and learning capabilities (not only investing in human and physical capital) (Nelson and Peck, 1999; Dahlman, 1994; Hobday, 1995; Kim, 1998). From this perspective, the assimilation of increasingly modern technologies and the possibility of other important changes in the industrial structure of these economies gave rise to a process of learning, innovation and entrepreneurial efforts that were critical to get a comprehensive explanation on economic growth in East Asian countries (Pack and Nelson, 1999). In fact, the development of new technologies in new sectors requires the expansion of a new set of entrepreneurial skills and firm management capabilities to improve the capacity to compete in new markets (Pack and Nelson, 1999). Accordingly, the policy environment in East Asian countries was critical to firms' success as a third factor to the conventional production function, expanding educational attainments by well-trained managers, engineers and applied scientists capable to provide a competitive advantage to identify new opportunities and an effective learning process (Pack and Nelson, 1999). From this perspective, the possibility of developing a sustained competitive advantage among 
indigenous firms imply an effective learning process to master new technologies from industrialised countries (López-Rodríguez and García-Rodríguez, 2005; Rodríguez et al., 2015).

In the case of NAFTA, it was said that the inclusion of Mexico in this agreement would enhance its economic performance through acquiring new technologies from abroad. However, technology transfer has been unbalanced between Mexico and its commercial partners in North America (Lederman and Maloney, 2006; Weisbort et al., 2014). Even if some positive results have been achieved in the case of Mexico, trade liberalisation and other economic policies implemented in this country during the last twenty years have not been enough to guarantee higher levels of economic performance (Rodríguez and Gómez, 2011; Weisbort et al., 2014). Actually trade liberalisation has been helpful but not enough to catch up with the level of technology progress in Canada and the United States (Lederman and Maloney, 2006). In fact, Mexican firms need to develop an absorptive capacity to successfully adopt new technologies from abroad. In this sense, absorptive capacity is a function of the level and rate of change of R\&D developed by indigenous firms (Cohen and Levinthal, 1989; Lederman and Maloney, 2006). In short, trade liberalisation and FDI would be an adequate explanation for TFP in many developing countries (Lederman and Maloney, 2006). Yet, some researchers have suggested that trade liberalisation and FDI, on the one hand, and improvements in the absorptive capacity and other major changes in the industrial structure to support learning, innovation and entrepreneurial efforts, on the other, have been critical to effectively achieve higher levels of economic growth and development in many emerging economies (Pack and Nelson, 1999).

\subsection{Foreign direct investment and technological spillovers}

The international economics theory explains how the availability of raw materials, tariff and non-tariff barriers, low wages, risk diversification, transportation costs, and fiscal incentives may attract FDI from other countries (Appleyard and Field, 2013; Krugman et al., 2014). For example, raw materials availability may positively impact FDI given that MNEs take advantage from low-priced resources to reduce their production costs. The presence of tariffs and non-tariff barriers may also have a positive impact on FDI in that MNEs are advantageous to operate in protected local markets. In the same way, low wages may positively influence MNEs' investment decisions when they are labour-intensive producers. In addition, MNEs decide to invest in foreign markets for strategic reasons to protect their market shares. Risk diversification drives firms' decisions to place certain assets of their investments in other markets as a means of protection. Yet, the presence of transportation costs may impact firm's investment decisions given that FDI tends to replace exports as costs of transportation get higher. Finally, fiscal incentives granted by governments in some countries can produce an advantage to attract FDI inflows.

At a different level of analysis, some researchers have suggested that FDI should not be seen only as a transfer of capital to a host country, but also as a combination of capital, business organisation and new technology transfer (Dussel et al., 2007; Heijs, 2006). Indeed, the effects generated by FDI inflows on the industrial structure of a host country could be of two types (Olechko, 2004). First, there is direct effects from FDI where foreign investors do not acquire all the benefits from the efficiency generated by foreign investments (Heijs, 2006; Olechko, 2004). Instead, direct effects imply the possibility of achieving some gains from inward FDI of a different type, such as higher wages for local workers, lower prices for local consumers, and tax revenues for local governments (Olechko, 2004). Accordingly, direct effects basically refer to the fundamental role played by FDI in the process of economic development that allows achieving higher levels of modernisation in a specific productive system (Heijs, 2006). However, in the case of Mexico, some researchers have suggested that technology spillovers from FDI have contributed to improve labour productivity, economic growth, firms' competitiveness, and so forth (Rivas-Aceves and Puebla-Méndez, 2016). Moreover, modernisation of the existing production capacity in emerging economies could be achieved through mergers and acquisitions induced by FDI, but also by the introduction of new forms of managing and marketing in organisations (Heijs, 2006). Therefore, the introduction of innovations resulting from direct effects of FDI in emerging economies will have a positive effect on markets through developing new sectors or revitalising other existing sectors (Heijs, 2006).

Second, there are other indirect effects generated in the form of technology spillovers (Olechko, 2004). Indirect effects from inward FDI are based on the diffusion of knowledge and technologies among indigenous firms in the from technology spillovers, concerning to the possibility of achieving some benefits by means of technology transfer, production chains, training of human resources, and local business development (Elías et al., 2006). Indirect effects and externalities from FDI in host countries are delivered in the form of new knowledge and innovation diffusion, including technical progress, management and development of organisational skills (e.g. technical, productive and commercial), as well as human capital and innovation capacity improvements (Elías et al., 2006). In this regard, there are two important explanations on the existence of technology externalities (Heijs, 2006). On the one hand, foreign subsidiaries entering into local markets may contribute to explain their expansion through developing non-existing assets and innovations (Heijs, 2006). On the other, inward FDI forces indigenous firms to adjust their strategic decisions to protect their market shares and profit margins (Heijs, 2006). Nevertheless, technological capabilities may contribute to acquire the skills needed to develop a path of sustained growth, mainly knowledge and skills needed to obtain, use, absorb, adapt, improve and generate new technologies (Bell and Pavitt, 1993; Lall, 1992). In short, the presence and intensity of technology spillovers depend on firms' absorptive capacity, as well as the level of economic development of the host country that allows absorbing, adapting, and improving technologies from abroad (Brown and Dominguez, 2004). Thus, the complexity of a production process, the technology used by foreign companies, the degree of economic development, and other domestic firms' technological capabilities are essential to develop an absorptive capacity (Vera-Cruz and Dutrénit, 2007). 
Finally, the level and similarity of technological capabilities between indigenous firms and foreign firms become a basic condition to establish appropriate links to developing a reciprocal learning process (Narula, 2004). In this regard, competitive firms with superior absorptive capacity will take advantage from technological spillovers (Narula, 2004). Accordingly, when domestic firms are technologically far from foreign firms, they would be less capable of learning from new technologies and knowledge (Javorcik, 2002, 2004). Actually the process of technology spillovers requires an effective and comprehensive policy to provide a supporting environment for investments and to create adequate institutional and human capabilities (OECD, 2008). Evidence demonstrates that in the case of Mexico, spillover effects have only occurred in some sectors with high levels of technological capabilities developments (Blomstrom and Pearsson, 1983; Brown and Dominguez, 2004).

\subsection{Foreign Direct Investment in Mexico}

The Foreign Direct Investment in Latin America and the Caribbean 2015 report released by the Economic Commission for Latin America and the Caribbean (ECLAC, 2015) positioned Mexico as the second largest recipient of inward FDI in Latino America. Even if FDI in Latin America countries has been significantly important, it only represented a small fraction of the GDP in this region during last years. In the case of Mexico, for example, the manufacturing sector accounted $70 \%$ of the total inward FDI (ECLAC, 2015). However, in this country, the total amount of net capital inflows and reinvested profits of transnational corporations have shown a growing trend since the 1990’s (Figure 1) (ECLAC, 2015).

Figure 1. Mexico Inward FDI, 1980 - 2015

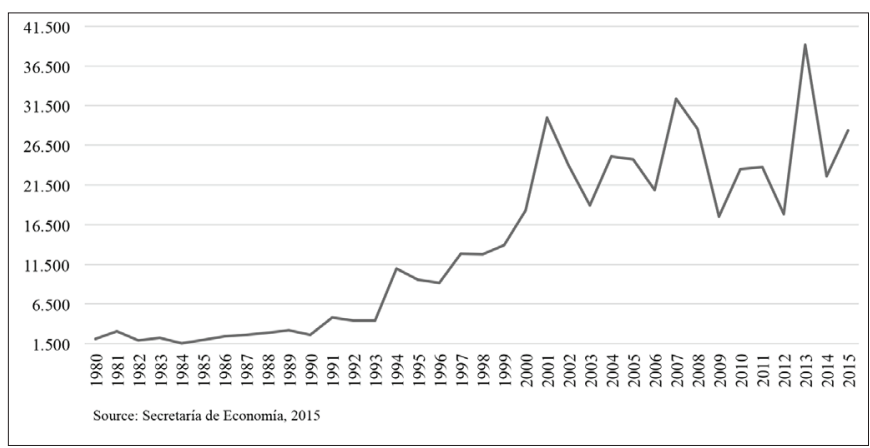

In the case of Latin America countries, Brazil, Chile and Mexico have been the most important recipients of inward FDI in the last decades (Figure 2). Specifically, in the case of Mexico, the Foreign Direct Investment in Latin America and the Caribbean 2015 report mentions that FDI inflows in this country have been more important during the lately past years than in the previous decade of the 1990s (ECLAC, 2015). However, some stylised facts characterising FDI inflows in Mexico can be established (ECLAC, 2015). First, Mexico was one of the most important recipients of FDI inflows in this region during the last years. Second, FDI inflows in this country accounted more than $\$ 40,000$ dollars in 2013 , and more than $\$ 25,000$ dollars in 2014 . Third, the automotive industry in Mexico was the largest FDI recipient in 2014 , absorbing $\$ 4,308$ billion dollars of the total investment in this country ( $\$ 12.87$ billion dollars). Fourth, financial services in Mexico received approximately one third of total FDI inflows in 2014 being the dominant sector in this country in relation to the total investment received from abroad. Finally, financial services represent $25 \%$ of the total FDI in this country (ECLAC, 2015). In short, data of FDI inflows in Mexico shows the importance of foreign investment in the automotive, financial services and natural resources sectors (ECLAC, 2015).

Figure 2. Latin America Inward FDI by Country, 2001 - 2014

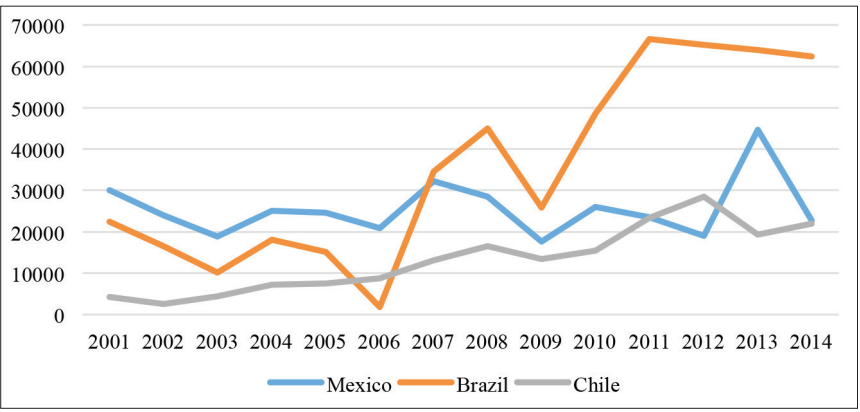

On the other hand, evidence demonstrates that the United States remains the largest foreign investor in Mexico, accounting more than $30 \%$ of the total FDI inflows in this country during the last years. Actually the United States invested in Mexico more than in the previous decade and the two-year average inward of FDI ever recorded in this country (Figure 3). It is important to mention that Spain, the Netherlands, Belgium, Canada, Germany and Japan are also important foreign investors in Mexico (ECLAC, 2015).

Figure 3. Mexico Inward FDI by Country of Origin, 2006 - 2014

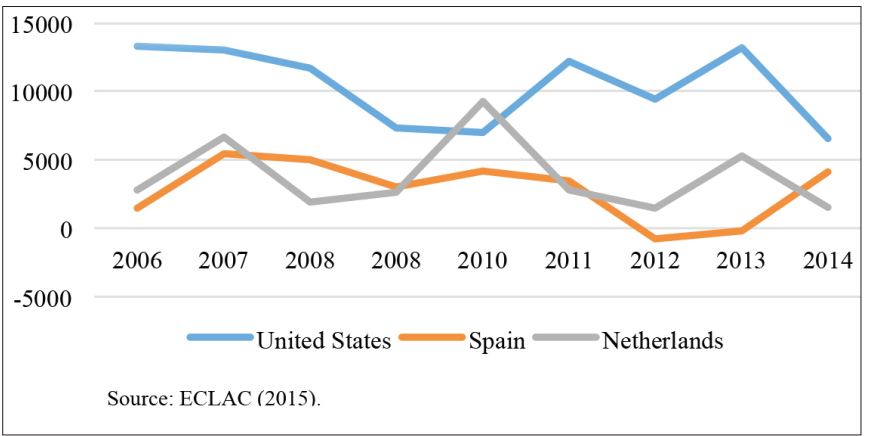

The importance of FDI in emerging economies should continue spilling over indigenous firms, bringing technology advancements into firms. In the case of Mexico, foreign investment mostly concerns to greenfield projects which create or expand the production capacity. In this case, FDI inflows generate different impacts on the economy. However, in the case of this country, not all FDI is invested in hightech manufacturing sectors, limiting the potential of transferring knowledge for improving the local technology capacity.

According to the ECLAC report (ECLAC, 2015), the main trends of FDI in Latin America countries will remain stable in the next years. Yet, the political facts recently observed in the United States may change these trends in the case of Latin America countries in general, 
and particularly in the case of Mexico. Importantly, outflow FDI from emerging countries has been recognised as an important source of investments in other developing and developed economies during the last years. For instance, twenty of the largest mergers and acquisitions carried out by Latin America firms originated in Mexico (ECLAC, 2015).

From a different perspective, scholars have analysed the possibility of finding technology spillovers from inward FDI in the case of emerging economies. The case of Mexico has been studied by many scholars (Jordan, 2011; Lederman and Maloney, 2006; Rodríguez-Pose and Villarreal-Peralta, 2015; Romo, 2005). Jordan (2011), for example, finds substantial evidence of FDI impact on higher levels of local dynamics markets, depending on the level of the absorptive capacity of suppliers, the size of the technology gap between producer and suppliers, and the provision of producer firms. Lederman and Maloney (2006) mention that trade liberalisation and NAFTA have been helpful, but not enough to help Mexico catching up with the level of technological progress in the United States and Canada. RodríguezPose and Villarreal-Peralta (2015) analyse the possibility of finding technological spillovers across 32 states of Mexico, stressing the importance of the relationship between regional economic growth and R\&D investment in areas with favourable social conditions for innovation. Finally, Romo (2005) analyses FDI as an engine to boost economic development. In fact, this author pointes out the importance of inward FDI in the case of emerging economies as a mechanism to acquire new technologies from abroad.

\section{The Model}

Data from Encuesta Nacional de Empleo, Salarios, Tecnología y Capacitación en el Sector Manufacturero (National Survey of Employment, Salaries, Technology and Training in the Manufacturing Sector, ENESTYC) and Encuesta sobre Investigación y Desarrollo de Tecnología (Survey of Investment and Technology Development, ESIDET) released by Instituto Nacional de Estadística y Geografía (National Institute for Statistics and Geography, INEGI) are used to test the hypotheses in this research. The dependent variable, Technology Capacity Index (TCI), in Model 1 and Model 2 aims to capture the possibility of finding evidence of technology capacity developments from inward FDI in Mexico. However, other variables are also included in these models to test evidence of technology capacity developments in the case of the Mexican manufacturing sector.

The independent variables in Model 1 are Foreign Direct Investment (FDI), Exports (XS), Large and Medium Size Firms (LMF), Small Size Firms (SF), Age of Firms with 15 years or less in Markets (E1), and Age of Firms between 15 and 25 Years in Markets (E2). On the other hand, the independent variables in Model 2 are Foreign Direct Investment (FDI), Exports (XS), Innovation (INN), Research and Development (R\&D), and Introduction of New Processes (PR). Accordingly, seven hypotheses were established in this research to test the presence of technology capacity developments in Mexico. Hypothesis 1 and Hypothesis 2 aim to capture the importance of FDI to develop technology capabilities in the manufacturing sector of Mexico
(Mahmood and Singh, 2003). However, this process is developed through the association between the presence/intensity of FDI and trade liberalisation, on the one hand, and productivity of receiving firms/importing firms, on the other (Aitken and Harrison, 1999; Blomström and Kokko, 1998; Blomström and Persson, 1983; Gorg and Greenway, 2004; Markusen, 2002). From the same theoretical perspective, other studies identify the link between innovation and exports to explain the development of firms' competitiveness in the case of emerging economies (Enjolras et al., 2016). Therefore, in the case of Mexico, the following two hypotheses can be established in the case of Mexico:

Hypothesis 1: Increases in FDI inflows may positively explain the presence of technology capabilities developments in Mexico $\left(\beta_{1}>0\right)$.

Hypothesis 2: The diffusion of new technologies that increases exports competitiveness may positively explain the presence of technology capabilities developments in Mexico $\left(\beta_{2}>0\right)$.

From the perspective of the assimilation view of growth, however, major changes in the structure of industries in emerging economies should facilitate the assimilation of new technologies from abroad. In this case, the main variables allowing these changes are firm size and sector specialisation (Pack and Nelson, 1999). Indeed, this idea suggests that firm evolution from a small size to a large size would be an indicator of this kind of changes. This argument is Schumpeterian in nature given that Schumpeter's idea on innovation is associated to a two-step evolving process (Fontana et al., 2012; Gómez and Rodríguez, 2012; Malerba, 2005): Schumpeter Mark I pattern (1934) and Schumpeter Mark II pattern (1942). Schumpeter Mark I considers that small firms are more innovative than large firms. In fact, Schumpeter Mark I industries are characterised by a turbulent environment with relatively low entry barriers (Fontana et al., 2012). Accordingly, firms in Schumpeter Mark I are more flexible to adapt to changing turbulent environments through a 'creative destruction' process with successful innovating entrants that replace incumbent firms (Fontana et al., 2012; Malerba, 2005; Narula, 2004). By contrast, Schumpeter Mark II industries suggests a stable environment with relatively high entry barriers in which innovations are generated and developed by large established firms (Fontana et al., 2012; Narula, 2004). In this sense, an oligopolistic market structure with large established firms and important R\&D activity characterises Schumpeter Mark II as the main source of innovation and technology change. In Schumpeter Mark II industry technological competition assumes the form of 'creative accumulation' with incumbent firms introducing innovation developments (Fontana et al., 2012; Malerba, 2005). As a result, two other hypotheses can be established in the case of Mexico:

Hypothesis 3a: The existence of large and medium size firms may positively explain the presence of technology capabilities developments in Mexico $\left(\beta_{3}>0\right)$.

Hypothesis 3b: The existence of small size firms may positively (or not) explain the presence of technology capabilities developments in Mexico $\left(\beta_{4}>0\right.$ ?). 
In this way, it is expected that younger firms will be more innovative that older firms. The fact is that younger firms are more disposal to adapt or create new markets by developing innovations. Nevertheless, some scholars have suggested that older firms are more innovative than younger firms in that older firms are associated to resources availability for R\&D (Savino and Petruzzelli, 2012; Withers et al., 2011; Noordin and Mohtar, 2014). However, there is not strong evidence that support this proposition (Noordin and Mohtar, 2014). Therefore, the following two hypotheses can be stated in the case of Mexico:

Hypothesis 4a: Firms with 15 years or less in markets may positively explain the presence of technology capabilities developments in Mexico $\left(\beta_{5}>0\right)$.

Hypothesis 4b: Firms with more than 15 years in markets may negatively explain the presence of technology capabilities developments in Mexico $\left(\beta_{6}<0\right)$.

In addition, data from the Survey of Investment and Technology Development (ESIDET) allows testing other three hypotheses. Model 2 uses data on innovation developments, R\&D spending, and introduction of new processes to test these hypotheses. However, these variables may confirm the presence of technology capacity developments that may be spilling over the rest of the economy. Indeed, Model 2 tests the presence of technology capabilities in relation to the efforts carried out by firms to develop innovations, and thus the following three hypotheses can be established in the case of Mexico:

Hypothesis 5: The development of innovations may positively explain the presence of technology capabilities developments in Mexico $\left(\beta_{7}>0\right)$.

Hypothesis 6: Firm spending in R\&D may positively explain the presence of technology capabilities developments in Mexico $\left(\beta_{8}>0\right)$.

Hypothesis 7: The introduction of new processes into firms' production systems may positively explain the presence of technology capabilities developments in Mexico $\left(\beta_{9}>0\right)$.

Ordinary least squares (OLS) are used to compute Model 1 and Model 2. Specifically, pooled OLS are applied to test changes over time between explanatory and dependent variables. The matrix approach used in this research allows establishing the estimation procedure as follows:

$$
Y_{i}=Z_{i} \beta+\varepsilon_{i}, \text { where } Z_{i}=\left[X_{i t} K_{i t}\right]
$$

$Y_{i}$ in this equation is a vector of the dependent variable, $Z_{i}$ is a matrix of explanatory variables, and $\varepsilon_{i}$ is a vector of errors in the model. The estimators in this equation are estimated applying pooled OLS methods. Therefore, the estimators can be represented as follows:

$$
\hat{\hat{\beta}}_{M C A}=\left(Z_{i}^{\prime} Z_{i}\right)^{-1}\left(Z_{i}{ }^{\prime} Y_{i}\right)
$$

Accordingly, it would be possible to establish a more precisely relationship between the relations evaluated in these models when changes in the variables result from time passing (Ezequiel, 2013; Humérez, 2013). The objective is thus to test the possibility of finding a relationship between inward FDI and technology capacity developments in the manufacturing sector of Mexico, as well as other variables included in the models. The models estimated in this research are cross-sectional with $i=9$ sectors, and $t=1992,1995,1999,2001,2005$ and 2012. In this regard, Model 1 is estimated as follows:

$$
T C I_{i t}=\beta_{0}+\beta_{1} F D I_{i t}+\beta_{2} X S_{i t}+\beta_{3} L M F_{i t}+\beta_{4} S F_{i t}+\beta_{5} E 1_{i t}+\beta_{6} E 2_{i t}+e_{i t}
$$

Table 2 shows the variables of Model 1. The dependent variable in this model, Technology Capacity Index (TCI), depends on the independent variables Foreign Direct Investment (FDI), Exports (XS), number of Large and Medium Size Firms (LMF), number of Small Firms (SF), number of firms with 15 years or less in the market (E1), and number of firms between 15 and 25 years in the market (E2).

Table 2. Model 1: variables description

\begin{tabular}{lcl}
\hline \multicolumn{1}{c}{ Name } & Variable & \multicolumn{1}{c}{ Description } \\
$\begin{array}{l}\text { Technology Capacity } \\
\text { Index }\end{array}$ & TCI & $\begin{array}{l}\text { Logarithm of the technology } \\
\text { capacity index. }\end{array}$ \\
$\begin{array}{l}\text { Foreign Direct Investment } \\
\text { Exports }\end{array}$ & FDI & $\begin{array}{l}\text { Percentage of foreign capital to } \\
\text { total capital of the firm. }\end{array}$ \\
$\begin{array}{l}\text { Large and Medium Size } \\
\text { Firms }\end{array}$ & LMF & $\begin{array}{l}\text { Logarithm of foreign sales. } \\
\text { Logarithm of the number of } \\
\text { large and medium size firms. }\end{array}$ \\
$\begin{array}{l}\text { Small Size Firms } \\
\text { Years or Less in Markets }\end{array}$ & SF & $\begin{array}{l}\text { Logarithm of the number small } \\
\text { firms. }\end{array}$ \\
$\begin{array}{l}\text { Age of Firms between } 15 \\
\text { and } 25 \text { Years in Markets }\end{array}$ & E2 & $\begin{array}{l}\text { Logarithm of the number of } \\
\text { firms that have 15 years or less } \\
\text { in the market. }\end{array}$ \\
\hline
\end{tabular}

On the other hand, Table 3 shows how the dependent variable, Technology Capacity Index (TCI), is computed. Indeed, the Technology Capacity Index (TCI) comprises three different set of variables drawn from the ENESTYC: (i) learning and investment, (ii) production, and (iii) linkage with other firms. In this case, dimensions, units and values are defined for each set of variables (Table 3 ). 
Table 3. Model 1: Technology Capacity Index (TCI) in the Mexican manufacturing sector (ENESTYC)

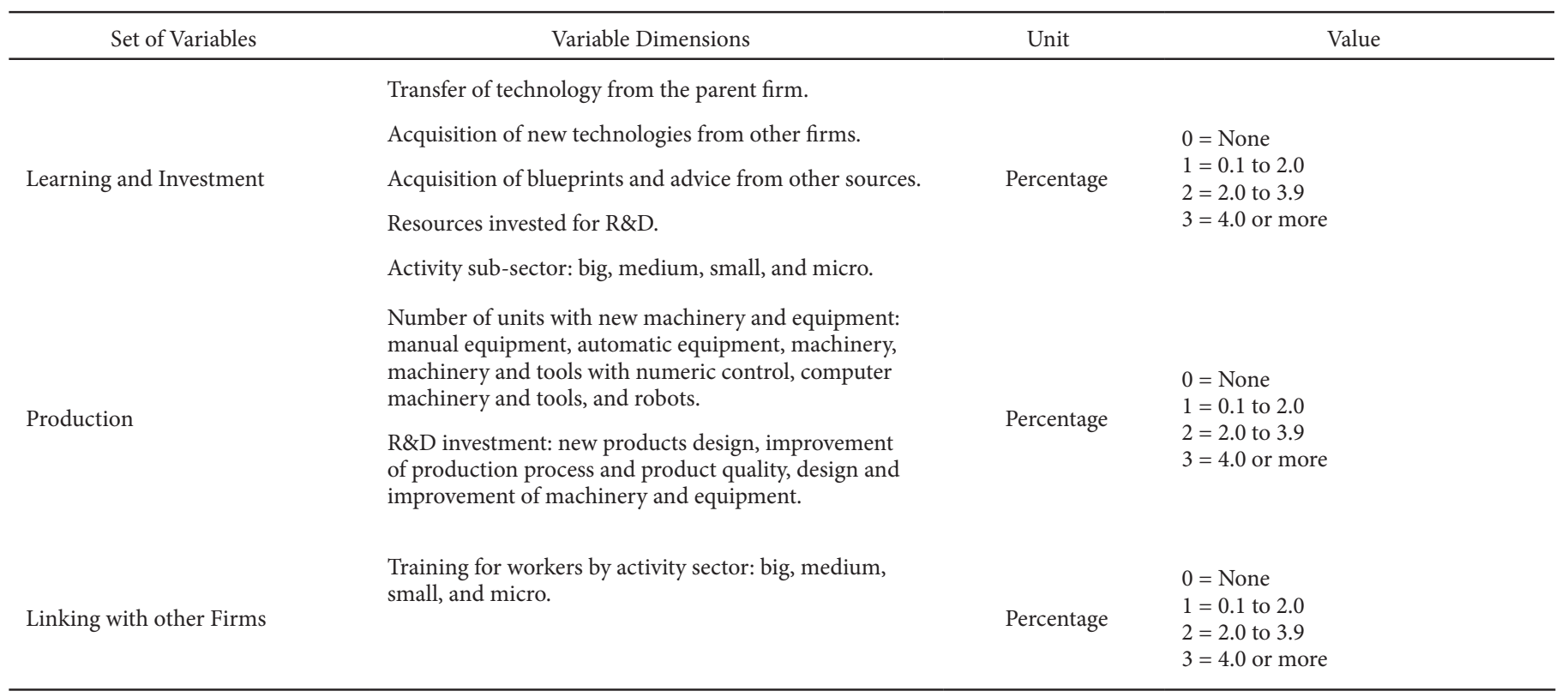

Source: Adapted from Brown and Domínguez (2004), and Pérez and Pérez (2009).

It is important to mention that ENESTYC is not applied since 2012. In its place, ESIDET was applied in 2012. However, both surveys allow getting data on technology and innovation activity in the manufacturing sector of Mexico. Nevertheless, the change in the source of information implies the need to estimate a new model:

$$
T C I_{i t}=\beta_{0}+\beta_{1} F D I_{i t}+\beta_{2} X S_{i t}+\beta_{7} I N N_{i t}+\beta_{8} R \& D_{i t}+\beta_{9} P R_{i t}+e_{i t}
$$

In Model 2, variables were defined searching to reflect the level of technological developments in the manufacturing sector of Mexico accordingly to the taxonomy proposed by Lall (1992), Brown and Domínguez (2004), Pérez and Pérez (2009), and others.
Table 4. Model 2: variables description

\begin{tabular}{|c|c|c|}
\hline Name & Variable & Description \\
\hline $\begin{array}{l}\text { Technology Capaci- } \\
\text { ty Index }\end{array}$ & TCI & $\begin{array}{l}\text { Logarithm of the technology } \\
\text { capacity index. }\end{array}$ \\
\hline $\begin{array}{l}\text { Foreign Direct } \\
\text { Investment }\end{array}$ & FDI & $\begin{array}{l}\text { Percentage of foreign capital to } \\
\text { total capital of the firm. }\end{array}$ \\
\hline Exports & XS & Logarithm of foreign sales. \\
\hline Innovation & INN & $\begin{array}{l}\text { Number of firms developing } \\
\text { innovations. }\end{array}$ \\
\hline $\begin{array}{l}\text { Research and De- } \\
\text { velopment }\end{array}$ & $\mathrm{R} \& \mathrm{D}$ & $\begin{array}{l}\text { Number of firms investing in } \\
\text { research and development. }\end{array}$ \\
\hline $\begin{array}{l}\text { Introduction of } \\
\text { New Processes }\end{array}$ & PR & $\begin{array}{l}\text { Number of firms introducing } \\
\text { new processes into their produc- } \\
\text { tion systems. }\end{array}$ \\
\hline
\end{tabular}

As in Model 1, the Technology Capacity Index (TCI) in Model 2 is considered as the dependent variable (Table 3), and then FDI, Exports (XS), Innovation (INN), Research and Development (R\&D) and Introduction of New Processes (PR) as the independent variables (Table 4). 
Table 5. Model 2: Technology Capacity Index (TCI) in the Mexican manufacturing sector (ESIDET)

\begin{tabular}{|c|c|c|c|}
\hline Set of Variables & Variable Dimensions & Unit & Value \\
\hline Learning and Investment & $\begin{array}{l}\text { Extramural R\&D investment in technology development. } \\
\text { Intramural R\&D investment in technology development. } \\
\text { Intramural R\&D investment in new products development. } \\
\text { Firms' spending in human resources training (higher education graduate programs). } \\
\text { Firms' spending in human resources training (R\&D technology developments). } \\
\text { Spending in technology services. } \\
\text { Number of firms acquiring new technologies for improving their production capac- } \\
\text { ity and/or acquiring new machinery and equipment for improving their production } \\
\text { processes and/or absorbing new technologies and/or adapting new technologies for } \\
\text { improving their levels of efficiency and/or developing their own technologies and/or } \\
\text { patenting new products or technologies and/or patenting new products and technolo- } \\
\text { gies for their own use and/or patenting new technologies for licensing. }\end{array}$ & Percentage & $\begin{array}{l}0=\text { None } \\
1=1 \text { to } 10 \\
2=10 \text { to } 30 \\
3=30 \text { or more }\end{array}$ \\
\hline Production & $\begin{array}{l}\text { Firms' researchers and technologists developing intramural R\&D projects. } \\
\text { Firms' technicians developing intramural R\&D projects. } \\
\text { Firms' management personal supporting intramural R\&D projects. } \\
\text { Firms' management personal supporting extramural R\&D projects. } \\
\text { Firms' personal supporting human resources training at higher education level. } \\
\text { Firms' personal trained for specialised technical tasks. }\end{array}$ & Percentage & $\begin{array}{l}0=\text { None } \\
1=1 \text { to } 10 \\
2=10 \text { to } 30 \\
3=30 \text { or more }\end{array}$ \\
\hline
\end{tabular}

Source: Adapted from Brown and Domínguez (2004), and Pérez and Pérez (2009).

In the same way, as in Model 1, Table 5 shows how the dependent variable, Technology Capacity Index (TCI), is computed following the methodology proposed by Brown and Domínguez (2004), Pérez and Pérez (2009), and others.

\section{Results}

The research methods used in these models are like those developed by Brown and Domínguez (2004) and Pérez and Pérez (2009), among others. Yet, some other studies analyse the case of Mexico, such as Armas (2017), Brown and Domínguez (2004), Brown and Guzmán (2014), Jordan (2011), Pérez and Pérez (2009), Rodríguez and Gómez (2011), Rodríguez-Pose and Villarreal-Peralta (2015), and Romo (2005). However, in this research, the TCI of the Mexican manufacturing sector was computed by means of using the taxonomy proposed by Lall (1992), and Bell and Pavitt (1993). Two panel data regression models were estimated using cross-sectional and time series data ( $i=9$ and $t=1992,1995,1999,2001,2005,2012)$. The models were tested for normality and homoscedasticity (White Test) to find out whether errors were homoscedastic and normally distributed (White, 1980). The analysis discussed in this section allows the possibility of finding technology capacity developments within the Mexican manufacturing sector.

Model 1 tests Hypotheses $1-4$. The values of Adjusted $R^{2}=0.8990$ and $F$-statistic $=66.31$ validate the results achieved in this model (Table 6). As predicted by Hypothesis 1, the variable FDI is positive and significant. Importantly, this unexpected result achieved in
Model 1 suggests that FDI in Mexico have been less important to explain TCI developments in this country. In the same way, FDI in Model 2 is positive and no significant, and thus the null hypothesis $\left(\beta_{1}=0\right)$ cannot be rejected $(t$-statistic $=1.26)$. This finding supports the idea that FDI and trade liberalisation in Mexico have not been enough to catch up with its North America commercial partners (Lederman and Maloney, 2006). In fact, this result also supports the idea that the assimilation view of growth should be an adequate theoretical explanation to explain this possibility only if FDI and trade liberalisation are accompanied by learning, entrepreneurship and innovation developments (Dahlman, 1994; Hobday, 1995; Kim, 1998; Pack and Nelson, 1999). In this regard, further results achieved in Model 2 will demonstrate the importance of innovation developments, $\mathrm{R} \& \mathrm{D}$ spending, and the process of incorporating new process by indigenous firms to develop higher levels of technology capacity in the manufacturing sector of Mexico.

Hypothesis 2 in Model 1 (and Model 2) suggests that the diffusion of new technologies increases exports competitiveness and thus the development of technology capabilities in the manufacturing sector of Mexico (Enjolras et al., 2016; Erdal and Göçer, 2015). In this case, the variable XS is positive and significant, and thus the null hypothesis $\left(\beta_{2}=0\right)$ can be rejected $(t$-statistic $=5.91)$. In Model 2, the null hypothesis is rejected $(t$-statistic $=2.95)$ in favour of the alternative hypothesis that explain the development of technology capabilities in this country when indigenous firms can learn and get new knowledge in foreign markets to locally accumulate technology capabilities becoming more competitive in international markets. 
Table 6. Regression results: Technology Capacity Index (TCI) in the manufacturing sector of Mexico

\begin{tabular}{|c|c|c|c|c|c|c|}
\hline \multirow{2}{*}{ Variable } & \multicolumn{3}{|c|}{$\begin{array}{c}\text { Model } 1 \\
\text { (Dependent Variable: TCI) }\end{array}$} & \multicolumn{3}{|c|}{$\begin{array}{c}\text { Model } 2 \\
\text { (Dependent Variable: TCI) }\end{array}$} \\
\hline & Coefficient (t-statistic) & $\begin{array}{l}\text { Standard } \\
\text { Error }\end{array}$ & Prob & Coefficient (t-statistic) & Standard Error & Prob \\
\hline $\mathrm{C}$ & $\begin{array}{l}-1.727931 \\
(-13.80)\end{array}$ & 0.125191 & 0.0000 & $\begin{array}{l}-0.954973 \\
(-1.54)\end{array}$ & 0.617866 & 0.1396 \\
\hline FDI & $\begin{array}{l}0.002213 \\
(1.86)\end{array}$ & 0.001186 & 0.0699 & $\begin{array}{l}0.001404 \\
(1.26)\end{array}$ & 0.001109 & 0.2218 \\
\hline XS & $\begin{array}{l}0.053614 \\
(5.91)\end{array}$ & 0.009059 & 0.0000 & $\begin{array}{l}0.106889 \\
(2.95)\end{array}$ & 0.036182 & 0.0085 \\
\hline LMF & $\begin{array}{l}0.232388 \\
(5.34)\end{array}$ & 0.043475 & 0.0000 & & & \\
\hline SF & $\begin{array}{l}-0.150162 \\
(-3.11)\end{array}$ & 0.048258 & 0.0035 & & & \\
\hline $\mathrm{E} 2$ & $\begin{array}{l}-0.030873 \\
(-1.46)\end{array}$ & 0.021060 & 0.1509 & & & \\
\hline INN & & & & $\begin{array}{l}0.001173 \\
(2.93)\end{array}$ & 0.000399 & 0.0088 \\
\hline $\mathrm{R} \& \mathrm{D}$ & & & & $\begin{array}{l}0.009460 \\
(2.69)\end{array}$ & 0.003510 & 0.0148 \\
\hline PR & & & & $\begin{array}{l}0.016987 \\
(2.52)\end{array}$ & 0.006733 & 0.0213 \\
\hline Adjusted $R^{2}$ & 0.8990 & & & 0.7426 & & \\
\hline$F$-statistic & 66.31 & & & 14.27 & & \\
\hline
\end{tabular}

Hypothesis $3 \mathrm{a}$ and Hypothesis $3 \mathrm{~b}$ test the Schumpeterian idea on the nature of innovation as a two-step evolving process (Schumpeter, 1934, 1942). The $t$-statistic in the case of $\operatorname{LMF}(t$-statistic $=5.34)$ allows rejecting the null hypothesis $\left(\beta_{3}=0\right)$ in favour of the alternative hypothesis, and suggesting that LMF is significant to explain the development of technology capabilities in the manufacturing sector of Mexico. In the same way, the $t$-statistic in the case of SF $(t$-statistic $=-3.11)$ allows rejecting the null hypothesis $\left(\beta_{4}=0\right)$ in favour of the alternative hypothesis that explain SF significant to the development of technology capabilities in the Mexican manufacturing sector. Nevertheless, a negative sign is obtained in the case of the variable SF in contrast to the case of the variable LMF. This finding suggests that small size firms in the manufacturing sector of Mexico are less disposal to innovate in relation to large and medium size firms, hypothesis already suggested by Schumpeter (Mark II characterised by stable oligopolistic markets and high entry barriers) (Schumpeter, 1942). Therefore, in the case of LMF, firm size has a positive impact on TCI through the development of absorptive capabilities and R\&D spending to advance new technologies. Importantly, in the case of Mexico, the negative sign in the case of variable SF may suggest that small size firms are less capable of developing innovations, and thus they only imitate technology developments carried out by large and medium size firms.
Hypothesis $4 \mathrm{a}$ and Hypothesis $4 \mathrm{~b}$ aims to capture the idea that older firms contribute more to develop technology capabilities. The variable E1 is positive and significant and thus the null hypothesis $\left(\beta_{5}=0\right)$ can be rejected $(t$-statistic $=4.73)$. Nevertheless, the variable E2 is negative and no significant, and thus the null hypothesis $\left(\beta_{6}=0\right)$ cannot be rejected $(t$-statistic $=-1.46)$. This finding is against the expected results suggesting that mature firms would be more innovative, and thus they contribute more to develop technology capabilities.

On the other hand, Hypotheses $5-7$ were tested in Model 2. The values of Adjusted $R^{2}=0.7426$ and $F$-statistic $=14.27$ validate the results achieved in this model (Table 6). However, the results achieved in Model 2 are not conclusive. As already mentioned in Model 1 , the variable XS shows a positive sign suggesting that trade liberalisation positively impact the development of technology capacity (TCI) through competition given that this effect improves firms' absorptive capacity for acquiring new technologies from abroad (Enjolras et al., 2016; Erdal and Göçer, 2015). As expected, Hypothesis 5 aims to capture the idea that innovation developments contribute to explain technology advances in the manufacturing sector of Mexico. In Model 2, the variable (INN) shows a positive sign suggesting that the process of innovation developments improve firms' 
absorptivecapabilities, and thusthenullhypothesis $\left(\beta_{7}=0\right)$ canberejected $(t$-statistic $=2.93)$ in favour of the alternative hypothesis that explain INN as a source of technology capabilities developments in the Mexican manufacturing sector.

Hypothesis 6, the number of firms developing R\&D projects, is positive and significant $(t$-statistic $=2.69)$ in relation to the dependent variable Technology Capacity Index (TCI). This result allows rejecting the null hypothesis $\left(\beta_{8}=0\right)$ in favour of the alternative hypothesis. Finally, Hypothesis 7 , the number of firms introducing new processes into their production systems (PR) shows a positive and significant value $(t$-statistic $=2.52)$ in relation to the dependent variable TCI, suggesting that firms generate new knowledge when applying new process into their production systems.

\section{Conclusions}

The literature on the development of technology capacity, technology spillovers, and inward FDI has traditionally been focused on the importance of technology transfer as a mechanism to catch up and develop a more competitive economy. In the case of Mexico, these analyses aim to identify the existence of technology spillovers from FDI to improve economic performance of national industries by means of using technologies and processes from abroad. It is argued that the presence of FDI has not been enough to close the technology gap between Mexico and other North American countries (Lederman and Maloney, 2006). Even if the results achieved in this research demonstrate the importance of FDI and the development of technology capabilities from multinational corporations, these results also demonstrate that technology spillovers have not spilled over the rest of the manufacturing sector in Mexico. Indeed, FDI in this country has only contributed to develop technological capabilities in sectors where multinational companies are established (e.g. highly specialised and knowledge-based industries). From this perspective, NAFTA has not generated the results expected in Mexico. Even more NAFTA has deepened the technological gap between Mexico and its commercial partners in North America.

On the other hand, the results achieved in this research support the idea that the assimilation view of growth is an adequate theoretical explanation to understand the low level of performance in the Mexican economy during the last years. In this sense, evidence suggests that the presence of FDI and MNEs in Mexico is not accompanied by innovation, entrepreneurship and learning developments. Moreover, these results also suggest that FDI in Mexico is only positively related to training and collaboration effects. Therefore, policy implications from this research suggest the importance of developing an absorptive capacity among indigenous firms in Mexico to successfully assimilate external knowledge and technologies from abroad.

\section{References}

Aitken, B.J., \& Harrison, A.E. (1999). Do domestic firms benefit from foreign direct investment? Evidence from Venezuela. American Economic Review, 89(3), 605-618. DOI: 10.1257/aer.89.3.605
Appleyard, D.R., \& Field, A.J. (2013). International Economics. Eighth edition. McGraw-Hill/Irwin, Boston.

Armas, E. (2017). La Generación de Derramas y Capacidades Tecnológicas en la Industria Manufacturera de México: Los Casos de la Ciudad de México y el Estado de Michoacán, 1992-2012. Doctoral Dissertation. Economic and Business Research Institute - Universidad Michoacana de San Nicolás de Hidalgo.

Behera, S.R. (2015). Do domestic firms really benefit from foreign direct investment? The role of horizontal and vertical spillovers and absorptive capacity. Journal of Economic Development, 40(2), 57-86.

Bell, M., \& Pavitt, K. (1993). Technological accumulation and industrial growth: contrast between developed and developing countries. Industrial and Corporate Change, 2(2), 157-210. DOI: 10.1093/ $\mathrm{icc} / 2.2 .157$

Blalock, G., \& Gertler, P.J. (2008). Welfare gains from foreign direct investment through technology transfer to local suppliers. Journal of International Economics, 74(2), 402-421. DOI: 10.1016/j.jinteco.2007.05.011

Blecker, R.A. (2003). The North American economies after NAFTA. International Journal of Political Economy, 33(3), 5-27.

Blecker, R.A. (2014). The Mexican and U.S. economies after twenty years of NAFTA. International Journal of Political Economy, 43(2), $5-26$.

Blomström, M., \& Kokko, A. (1998). Multinational corporations and spillovers. Journal of Economic Surveys, 12(3), 247-277. DOI: 10.1111/1467-6419.00056

Blomström, M., \& Persson, H. (1983). Foreign investment and spillover efficiency in an underdeveloped economy: evidence from the Mexican manufacturing industry. World Development, 11(6), 493501. DOI: $10.1016 / 0305-750 x(83) 90016-5$

Brown, F., \& Guzmán, A. (2014). Innovation and productivity across Mexican manufacturing firms. Journal of Technology Management \& Innovation, 9(4), 36-52. DOI: 10.4067/s0718-27242014000400003

Brown, F., Domínguez, L. (2004). Medición de las capacidades tecnológicas en la industria mexicana. Revista de la CEPAL, 83, 135-151.

Coe, D.T., \& Helpman, E. (1995). International R\&D spillovers. European Economic Review, 39(5), 859-887. DOI: 10.1016/00142921(94)00100-E

Cohen, W.M., \& Levinthal, D.A. (1989). Innovation and learning: the two faces of R\&D. Economic Journal, 99, 569-596. DOI: $10.2307 / 2233763$

Collins, S.M., \& Bosworth, B.P. (1996). Economic growth in East Asia: accumulation versus assimilation. Brookings Papers on Economic Activity, 1996(2), 135-203. DOI: 10.2307/2534621 
Dahlman, C.J. (1994). Technology strategy in East Asian developing economies. Journal of Asian Economics, 5(4), 541-572. DOI: 10.1016/ S1049-0078(10)80010-7

Dahlman, C.J., Ross-Larsen, B., \& Westphal, L.E. (1987). Managing technology development: lessons from newly industrializing countries. World Development, 15(6), 759-775. DOI: 10.1016/0305750x $(87) 90058-1$

Dowling, J.M. (1994). Is there an Asian industrial growth paradigm? Journal of Asian Economics, 5(4), 525-535. DOI: 10.1016/s10490078(10)80008-9

Dussel, P., Galindo, L.M., Loria, E., \& Mortimore, M. (2007). Inversión extranjera directa en México: desempeño y potencial: una perspectiva macro, meso, micro y territorial. Siglo XXI Editores, Secretaría de Economía, Facultad de Economía de la UNAM y Centro de Estudios China-México de la UNAM, Mexico.

ECLAC. (2015). Foreign Direct Investment in Latin America and the Caribbean 2013. United Nations, Santiago.

Elías, S., Fernández, R., \& Ferrari, A. (2006). Inversión Extranjera Directa y Crecimiento Económico: Un Análisis Empírico. Working Paper. Department of Economics. Universidad Nacional del Sur.

Enjolras, M., Camargo, M., \& Schmitt, C. (2016). SMEs' innovation and export capabilities: identification and characterization of a common space using data spatialization. Journal of Technology Management \& Innovation, 11(2), 56-69. DOI: 10.4067/s071827242016000200006

Erdal, L., \& Göçer, I. (2015). The effects of foreign direct investment on R\&D and innovations: panel data analysis for developing Asian countries. Procedia - Social and Behavioral Science, 195, 749-758. DOI: 10.1016/j.sbspro.2015.06.469

Ezequiel, U. (2013). Econometría y Datos Económicos. Working Paper. Universidad de Valencia. Spain.

Fontana, R., Nuvolari, A., Shimitzu, H., \& Vezzulli, A. (2012). Schumpeterian patterns of innovation and the sources of breakthrough inventions: evidence from a data-set or R\&D awards. Working Paper 24. School of Economics and Management. Technical University of Lisbon.

Gerschenkron, A. (1962). Economic Backwardness in Historical Perspective. A Book of Essays. Harvard University Press, Cambridge.

Glass, A.J., \& Saggi, K. (1998). International technology transfer and the technology gap. Journal of Development Economics, 55(2), 369398. DOI: 10.1016/S0304-3878(98)00041-8

Gómez, M., \& Rodríguez, J.C. (2012). The economic and strategic management debate on firm performance and technological change. Denarius, 24, 207-230.
Gorg, H., \& Greenaway, D. (2004). Much ado about nothing? Do domestic firms really benefit from foreign direct investment? World Bank Research Observer, 19(2), 171-197. DOI: 10.1093/wbro/lkh019 Hartman, S.W. (2010). NAFTA, the controversy. International Trade Journal, 25(1), 5-34. DOI: 10.1080/08853908.2011.532036

Heijs, J. (2006). El papel de las empresas extranjeras en el desarrollo tecnológico de las economías nacionales. Los Intangibles de la Internacionalización Empresarial, 830, 31-53.

Hobday, M. (1995). Innovation in East Asia: diversity and development. Technovation, 15(2), 55-63. DOI: 10.1016/0166-4972(95)96610-6

Humérez, J. (2013). Agrupamiento de Datos de Sección Cruzada. Working Paper. Universidad Mayor de San Simón. Bolivia.

Javorcik, B.S. (2002). Composition of Foreign Direct Investment and Protection of Intellectual Property Rights: Evidence from Transition Economies. World Bank, Policy Research Working Paper No 2786, Washington, D.C.

Javorcik, B.S. (2004). Does foreign direct investment increase the productivity of domestic firms? In search of spillovers through backward linkages. American Economic Review, 94(3), 605-627. DOI: $10.1257 / 0002828041464605$

Jordan, J.A. (2011). Local sourcing and technology spillovers to Mexican suppliers: how important are FDI and suppliers characteristics? Growth and Change, 42(3), 287-319. DOI: 10.1111/j.14682257.2011.00554.x

Kim, J., \& Lau, L.J. (1994). The sources of economic growth of the East Asian newly industrialized countries. Journal of the Japanese and International Economies, 8(3), 235-271. DOI: 10.1006/jjie.1994.1013

Kim, L. (1998). Imitation to Innovation: Dynamics of Korea's Technological Learning. Harvard Business School Press, Boston.

Krugman, P.R. (1994). The myth of Asia's miracle. Foreign Affairs, 73(6), 62-78.

Krugman, P.R., Obstfeld, M., \& Melitz, M. (2014). International Economics. Pearson.

Kuznets, P.W. (1994). Asian industrialization: is there a paradigm? Journal of Asian Economics, 5(4), 491-497. DOI: 10.1016/S10490078(10)80005-3

Lall, S. (1992). Technological capabilities and industrialization. World Development, 20(2), 165-186. DOI: 10.1016/0305-750x(92)90097-f

Lederman, D., \& Maloney, W.F. (2006). Innovation in Mexico: NAFTA is not enough. In Hoekman, B.M., \& Javorcik, B.S. (Eds.), Global Integration and Technology Transfer. Macmillan/World Bank. 
Liang, F.H. (2017). Does foreign direct investment improve the productivity of domestic firms? Technology spillovers, industry linkages, and firm capacity. Research Policy, 46(1), 138-159. DOI: 10.1016/j. respol.2016.08.007

López-Rodríguez, J., \& García-Rodríguez, R.M. (2005). Technology and export behaviour: a resource-based view approach. International Business Review, 14(5), 539-557. DOI: 10.1016/j.ibusrev.2005.07.002

Mahmood, I.P., \& Singh, J. (2003). Technological dynamism in Asia. Research Policy, 32(6), 1031-1054. DOI: 10.1016/s00487333(02)00109-9

Malerba, F. (2005). Industrial Dynamics and Innovation: Progress and Challenges. $32^{\text {nd }}$ Conference on the European Association for Research in Industrial Economics (EARIE). Porto, Portugal.

Markusen, J. (2002). Multinational Firms and the Theory of International Trade. MIT Press, Cambridge.

Narula, R. (2004). R\&D collaboration by SMEs: new opportunities and limitations in the face of globalisation. Technovation, 24(2), 153161. DOI: 10.1016/s0166-4972(02)00045-7

Noordin, M.A., \& Mohtar, S. (2014). Age: does it matter for firms to perform? International Journal of Academic Research in Business and Social Sciences, 4(3), 252-260. DOI: 10.6007/ijarbss/v4-i3/704

OCDE. (2008). OECD Information Technology Outlook 2008 Highlights. OECD Publishing, France.

Olechko, D.F. (2004). Inversión extranjera y productividad en México. Investigación Económica, 63(248), 147-173.

Pack, H., \& Nelson, R.R. (1999). The Asian miracle and modern growth theory. The Economic Journal, 109(457), 416-436. DOI: $10.1596 / 1813-9450-1881$

Pérez, A.A., \& Pérez, O. (2009). Competitividad y acumulación de capacidades tecnológicas en la industria manufacturera mexicana. Investigación Económica, 68, 159-187.

Prados de la Escosura, L. (2005). Gerschenkron Revisited. European Patterns of Development in Historical Perspective. Working Paper 05-79. Departamento de Historia Económica e Instituciones. Universidad Carlos III de Madrid. Spain.

Rivas-Aceves, S., \& Puebla-Méndez, A.D. (2016). Inversión extranjera directa y comercio exterior. Revista Mexicana de Economía y Finanzas, 11, 51-75.

Rodríguez, J.C., \& Gómez, M. (2011). Innovation trends in NAFTA countries: an econometric analysis of patent applications. Journal of Technology Management \& Innovation, 6(3), 116-125. DOI: 10.4067/ s0718-27242011000300009
Rodríguez, J.C., Gómez, M., \& Ramírez, K.N. (2015). Competitive advantage in knowledge-based firms of emerging economies: evidence from Mexico. International Journal of Globalisation and Small Business, 7(1), 39-58. DOI: 10.1504/ijgsb.2015.069035

Rodríguez-Pose, A., \& Villarreal-Peralta, E.M. (2015). Innovation and regional growth in Mexico: 2000-2010. Growth and Change, 46(2), 172-185. DOI: 10.1111/grow.12102

Romo, D. (2005). Inversión Extranjera, Derramas Tecnológicas y Desarrollo Industrial en México. FCE/CIDE, Mexico.

Saldaña, I. (2015). (March 28). Incierto que se dé el "milagro mexicano: Paul Krugman, El Universal (www.el-universal.com.mx).

Savino, T., \& Petruzzelli, A.M. (2012). Timing of Search and Innovation: The Moderating Effect of Firm Age and Innovation. Working Paper. Druid Society.

Schumpeter, J.A. (1934). The Theory of Economic Development. Harvard University Press, Cambridge.

Schumpeter. J.A. (1942). Capitalism, Socialism and Democracy. Allen \& Unwin, London.

Secretaría de Economía. (2015). Inversión Extranjera Directa: Base de Datos (www.se.gob.mx).

Storm, S., \& Naastepad, C.W.M. (2005). Strategic factors in economic development: East Asian industrialization 1950-2003. Development and Change, 36(6), 1059-1094. DOI: 10.1111/j.0012155x.2005.00450.x

Vera-Cruz, A., \& Dutrénit, G. (2007). Derramas de las MNCs a través de la movilidad de los trabajadores: evidencia de PYMES de maquilados en Ciudad Juárez. CONCYTEG, 2, 30-49.

Weisbrot, M., Lefebvre, S., \& Sammut, J. (2014). Did NAFTA help Mexico? An assessment after 20 years. Working Paper, Center for Economic and Policy Research (CEPR), Washington, D.C.

White, H. (1980). A heteroskedasticity-consistent covariance matrix estimator and a direct test for heteroskedasticity. Econometrica, 48(4), 817-838. DOI: $10.2307 / 1912934$

Withers, M.C., Drnevich, P.L., \& Marino, L. (2011). Doing more with less: the disordinal implications of firm age for leveraging capabilities for innovation activity. Journal of Small Business Management, 49(4), 515-536. DOI: 10.1111/j.1540-627x.2011.00334.x

Young, A. (1995). The tyranny of numbers: confronting the statistical realities of the East Asian growth experience. Quarterly Journal of Economics, 110(3), 641-680. DOI: 10.2307/2946695 
